\title{
Precambrian Nomenclature in Kansas
}

\author{
Robert S. Sawin ${ }^{1}$, Evan K. Franseen ${ }^{1}$, Greg A. Ludvigson ${ }^{1}$, \\ W. Lynn Watney ${ }^{1}$, and Ronald R. West ${ }^{2}$ \\ ${ }^{1}$ Kansas Geological Survey, 1930 Constant Avenue, Lawrence, Kansas 66047 \\ ${ }^{2}$ Emeritus Professor, Kansas State University, Manhattan, Kansas 66506 \\ ${ }^{1,2}$ Member, Stratigraphic Nomenclature Committee, Kansas Geological Survey
}

\begin{abstract}
The informal stratigraphic term "Precambrian" is replaced by formal nomenclature-Proterozoic and Archean Eonothems/Eons - and the informal term Hadean. The Phanerozoic Eonothem/Eon, representing all rocks younger than the Proterozoic, is added. The Proterozoic is further divided into Paleoproterozoic, Mesoproterozoic, and Neoproterozoic Erathems/Eras. The name Rice Formation (Scott, 1966) is abandoned, and the use of the informal term "Rice unit" is recommended. The proposed name Rice Series (Berendsen, 1994) is not accepted. These changes are adopted by the Kansas Geological Survey (KGS) and the stratigraphic nomenclature of Zeller (1968) has been revised accordingly.
\end{abstract}

\section{Introduction}

"Precambrian" is an informal stratigraphic term that comprises all rocks older than the Cambrian System/Period. The Precambrian spans the time from the formation of the Earth (about 4,568 million years before present [Ma]) to the beginning of the Cambrian Period (base of the Phanerozoic Eonothem/Eon), currently dated at $541.0 \pm 1 \mathrm{Ma}$ (Bleeker, 2004; Van Kranendonk et al., 2008; Van Kranendonk, 2012; Gradstein et al., 2012; and International Commission on Stratigraphy, 2013) (fig. 1).

The Precambrian is formally divided into the Proterozoic (youngest) and Archean (oldest) Eonothems/Eons; the boundary between these two eons is chronometrically set at 2,500 Ma (Robb et al., 2004), and the base of the Archean (also chronometrically set) is placed at 4,000 Ma (Van Kranendonk et al., 2008), the approximate age of the oldest known rocks. The period of time between the formation of the Earth and the beginning of the Archean Eon is informally referred to as the Hadean (Van Kranendonk et al., 2008; Van Kranendonk, 2012)

In Kansas, Precambrian rocks occur only in the subsurface. Radiometric age dates from wells that have penetrated basement rocks in Kansas range from 1,098 $\pm 3 \mathrm{Ma}$ to $1,780 \pm 20 \mathrm{Ma}$ (Van Schmus and Bickford, 1993), which places them in the Mesoproterozoic and upper Paleoproterozoic Erathems/Eras (fig. 1).

Rocks previously termed the Rice Formation of Scott (1966) - herein referred to informally as the Rice unit - probably occupy, at least in part, the Neoproterozoic Erathem/Era (Dickas, 1986; Berendsen and Barczuk, 1993; Cullers and Berendsen, 1993; Berendsen, 1994; Berendsen, 1997), although their age has not been determined by paleontologic or radiometric methods. These siliciclastic sedimentary rocks, deposited along the flanks of the Midcontinent Rift System (Van Schmus and Hinze, 1985), are placed in the Keweenawan Supergroup by most workers (see discussion by Anderson, 1990, p. 4).

\section{Discussion}

Proterozoic Eonothem/Eon. Proterozoic subdivisions were ratified by the International Union of Geological Sciences (IUGS) in 1990 (Plumb, 1991). The subdivision boundaries are not rockbased stratigraphic boundaries but are based on even (nearest 100 Ma) chronometric numbers (Robb et al., 2004; Van Kranendonk et al., 2008). In ascending order, the Proterozoic is divided into the Paleoproterozoic $(2,500$ to $1,600 \mathrm{Ma})$, Mesoproterozoic $(1,600$ to 1,000 Ma), and Neoproterozoic (1,000 to $541 \mathrm{Ma})$ Erathems/Eras (Van Kranendonk, 2012). Since the boundaries are chronometric and not rock-based, it is appropriate to use these names in Kansas. Based on major geologic, biologic, atmospheric, and geochemical events, some of the chronometric boundaries may be replaced by Global Stratotype Sections and Points (GSSPs) (Bleeker, 2004; Gradstein et al., 2004; Van Kranendonk et al., 2008; Van Kranendonk, 2012).

The only Proterozoic system/period that has been ratified by the IUGS is the uppermost Ediacaran System/Period of the Neoproterozoic Erathem/Era, whose GSSP in the Flinders Ranges, South Australia, defines the base (Knoll et al., 2006) and sets the age at $635 \mathrm{Ma}$ (International Commission on Stratigraphy, 2013). The coincident top of the Ediacaran System/Period, Neoproterozoic Erathem/Era, and Proterozoic Eonothem/Eon is defined by the GSSP at the base of the Cambrian System/Period (Brasier et al., 1994). The Ediacaran System/Period boundary has not been 


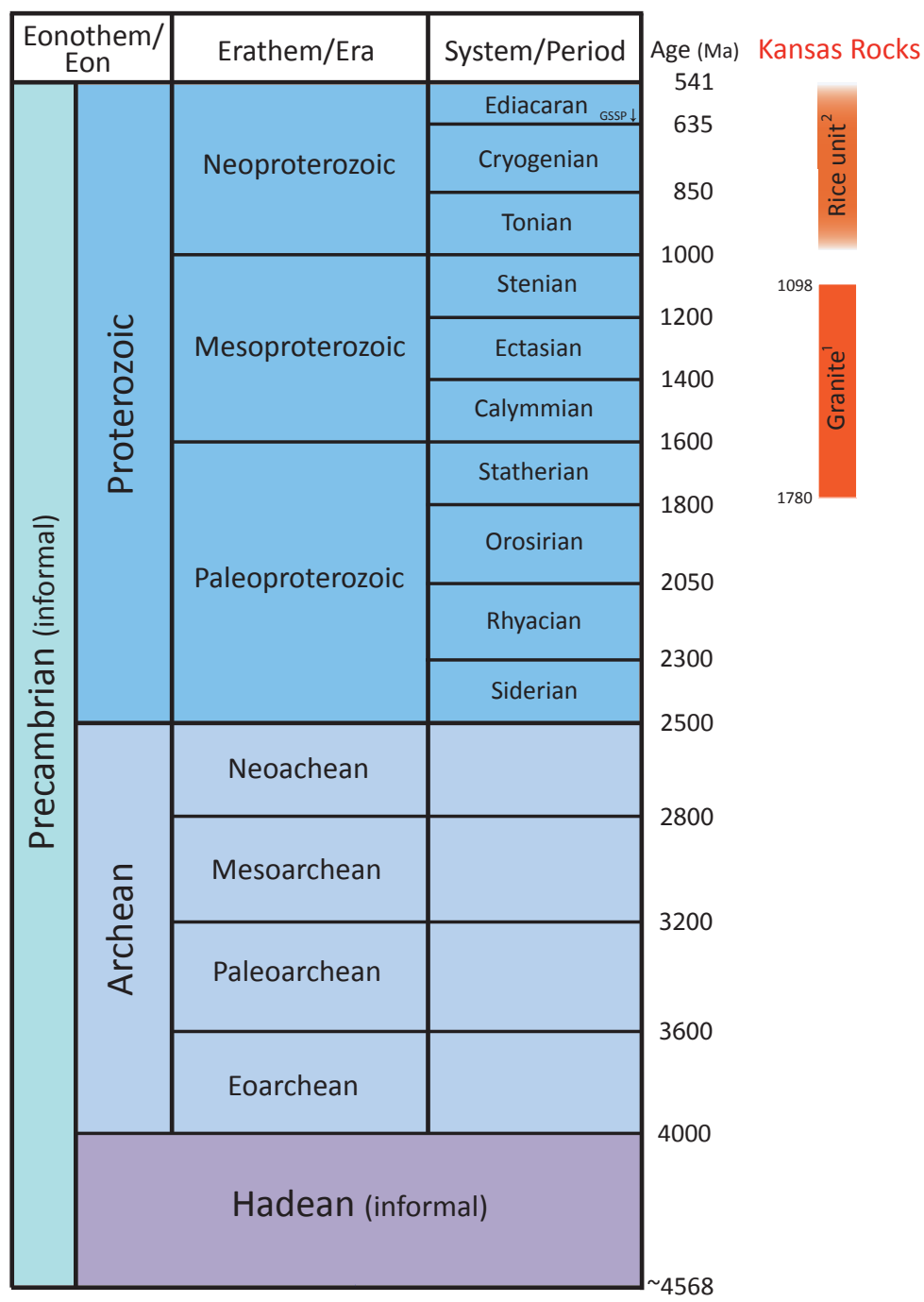

Figure 1-The Precambrian time scale (adapted from Gradstein et al., 2012, and International Commission on Stratigraphy, 2013). ${ }^{1}$ Van Schmus and Bickford, 1993. 2Dickas, 1986; Berendsen and Barczuk, 1993; Cullers and Berendsen, 1993; Berendsen, 1994; Berendsen, 1997.

established in Kansas. The nine underlying units are defined chronometrically. Therefore, they are periods only, not systems, until the GSSPs have been established. Because these units have not been ratified by the IUGS and have not been identified in Kansas, they are not adopted at this time.

Archean Eonothem/Eon. Archean Erathem/Era subdivisions, also defined chronometrically, have not been formally ratified by the IUGS, but their usage in the literature has become commonplace (Robb et al., 2004). In ascending order, the Archean is divided into the Eoarchean, Paleoarchean, Mesoarchean, and Neoarchean Erathems/Eras (Van Kranendonk, 2012). Period names for the Archean have not been established. Because Archean rocks are not known to occur in Kansas, the subdivisions are not used here.

Hadean (informal). The earliest period of Earth history, a time widely referred to informally as the "Hadean" following the initial definition by Cloud (1972), represents the period of time from the formation of the Earth (formation of the solar system) at about 4,568 Ma to the base of the Archean (4,000 Ma) (Van Kranendonk, 2012). The age of Earth's oldest dated rocks, found in northern
Canada, is placed at about 4,030 Ma (Van Kranendonk, 2012). Although Hadean rocks are not known from Kansas, the informal term is useful in referring to the period of time preceding the Archean and is therefore adopted.

Rice Formation. Rice Formation was proposed by R. W. Scott and adopted by the Kansas Geological Survey (Scott, 1966, p. 380) as the formal name for a "thick sequence of pre-Upper Cambrian feldspathic sandstone and shale in central Kansas" that "can be distinguished from other material in Kansas called 'granite wash."' Four drill holes in Rice and Ellsworth counties that penetrated 32, 309, 33, and $175 \mathrm{ft}(10,94,10$, and $53 \mathrm{~m})$ of this unit were designated "typical wells" (see Scott, 1966, table 1). In each of these wells, the rock unit overlying the Rice Formation is shown as the Cambrian Reagan Sandstone (Lamotte Sandstone in Zeller, 1968; shown on that chart as Lamotte [Reagan] Sandstone). Scott noted that the deepest penetration of the Rice Formation was 1,015 ft (309 m) and "no well penetrates the entire formation" (p. 380). The lateral extent of the Rice Formation shown by Scott, 1966 (p. 381, fig. 1) is limited to Kansas; a slightly different extent is depicted by Bickford et al., 1979. Scott (1966) was unsure of the age of the unit (hence the question mark in the title of his paper), stating it could be Precambrian, Cambrian, or span the Precambrian-Cambrian boundary.

Zeller (1968) recognized the Rice Formation as a formal unit but noted that, although the sequence locally exceeds $1,600 \mathrm{ft}(488 \mathrm{~m})$ in thickness, "the base of the formation has not been penetrated" (p. 11). Berendsen (1994) stated that no wells have penetrated the entire unit; the deepest penetration of the Rice Formation (Texaco \#1 Poersch, drilled in 1988 in Washington County, Kansas) is $8,450 \mathrm{ft}(2,576 \mathrm{~m})$.

Rice Formation Abandoned. The North American Stratigraphic Code (Code) clearly states that the definition of boundaries is one of the requirements for formally named geologic units (North American Commission on Stratigraphic Nomenclature, 2005, Article 3 [vi], p. 1,561). Articles 8, 10, 16, and 23 of the Code also address issues related to boundaries.

The lower boundary of Scott's Rice Formation has never been penetrated (Scott, 1966; Zeller, 1968; Berendsen, 1994). Because defined upper and lower boundaries are required for formally named geologic units, the Rice Formation was improperly defined and therefore in violation of the Code. Based on the Code, the formal name Rice Formation is invalid and abandoned herein.

Other concerns involving the formal status of the Rice Formation include the definition of the top boundary (Scott, 1966; Dickas, 1986), age (Scott, 1966; Zeller, 1968), limited distribution (Berendsen, 1994), uncertain lithostratigraphic correlations (Berendsen et al., 1988; Berendsen, 1994), and mappability (the Code states "wellestablished formations commonly are divisible into several widely recognizable lithostratigraphic units" [North American Commission on Stratigraphic Nomenclature, 2005, Article 24 (d), p. 1,569]).

When improperly defined units are formally abandoned, "recommendations must be made for classification and nomenclature to be used in its place" (North American Commission on Stratigraphic Nomenclature, 2005, Article 20, p. 1,565). Prior 
to Scott's 1966 proposal to formally name the Rice Formation, these rocks were referred to as "red clastics and arkose" (Koester, $1935)$ and "Rice sedimentary group" (Muehlberger et al., 1964). Scott (1966) stated he was substituting the name Rice Formation for Rice sedimentary group. The name Rice Formation appears both formally and informally in the literature (used mostly by authors associated with the Kansas Geological Survey). Therefore, following the Code's requirement to recommend classification and nomenclature for the abandoned Rice Formation, informal designation is appropriate for this unit. In assigning nomenclature, the Code specifically states that, regardless of capitalization, "Geographic names should be combined with the terms 'formation' or 'group' only in formal nomenclature" (North American Commission on Stratigraphic Nomenclature, 2005, Article 30 [h], p. 1,570). Thus, possible designations such as the "Rice formation" (lower case "f") or "Rice sedimentary group" are not acceptable. Based on the criteria outlined in the Code, the recommendation is to use the informal designation "Rice unit." The Code's recommendation, when making reference to an abandoned formal name, is to make sure its status is clear by using terms such as "abandoned" or "obsolete" and by using a phrase such as "previously termed the Rice Formation of Scott (1966)"
(North American Commission on Stratigraphic Nomenclature, 2005, Article 20 [d], p. 1,566).

Rice Series. Berendsen (1994) argued that Scott's Rice Formation cannot be correlated on lithostratigraphic criteria and, therefore, should not be classified as a formation. He proposed these rocks be termed "Rice Series" on the basis that "they occupy a clearly defined time-stratigraphic interval between the close of volcanism associated with major rift activities and deposition of the pre-Upper Cambrian or younger sedimentary rocks" (Berendsen, 1994, p. 4). According to the Code, "Series is a conventional chronostratigraphic unit that ranks below a system and always is a division of a system. A series commonly constitutes a major unit of chronostratigraphic correlation within a province, between provinces, or between continents" (North American Commission on Stratigraphic Nomenclature, 2005, Article 73, p. 1,582). Systems have not been defined for the Proterozoic in Kansas, so, based on the Code, without systems, there cannot be series. In addition, series names should minimally be applied at the province level. Because the age and duration of the Rice Series were not defined, and the term has been applied only to Kansas (Berendsen and Barczuk, 1993; Berendsen, 1994), the name Rice Series was improperly applied and its proposed adoption is rejected.

\section{Summary of Formally Adopted Precambrian Stratigraphic Nomenclature Changes}

The following changes are adopted by the Kansas Geological Survey, and Zeller is modified accordingly (see fig. 2 on page 4):

1. Archean and Proterozoic will be the Eonothem/Eon names for the "Precambrian" in Kansas. The term Precambrian is useful but should only be used informally. The corresponding Phanerozoic Eonothem/Eon, representative of all rocks Cambrian age and younger, is added.

2. Proterozoic Eonothem/Eon subdivisions-Paleoproterozoic, Mesoproterozoic, and Neoproterozoic Erathems/Eras - are recognized in Kansas.
3. The Archean Eonothem/Eon and Hadean are included in the chart although these rocks are not known to occur in Kansas.

4. The name Rice Formation (Scott, 1966) was improperly defined when given formal formation status and is hereby abandoned. It is recommended that this unit be referred to informally as the Rice unit.

5. The name Rice Series (Berendsen, 1994) was improperly applied and its proposed adoption is rejected. 
Zeller, 1968

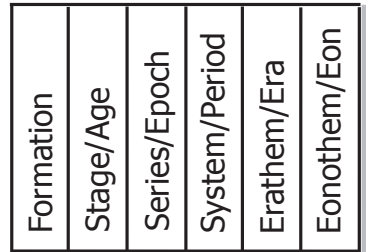

\begin{tabular}{|c|c|c|c|}
\hline 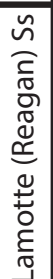 & 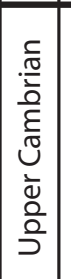 & 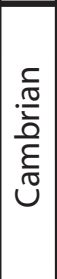 & 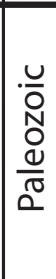 \\
\hline
\end{tabular}

$\stackrel{\Xi}{\simeq}$
KGS Nomenclature, 2013
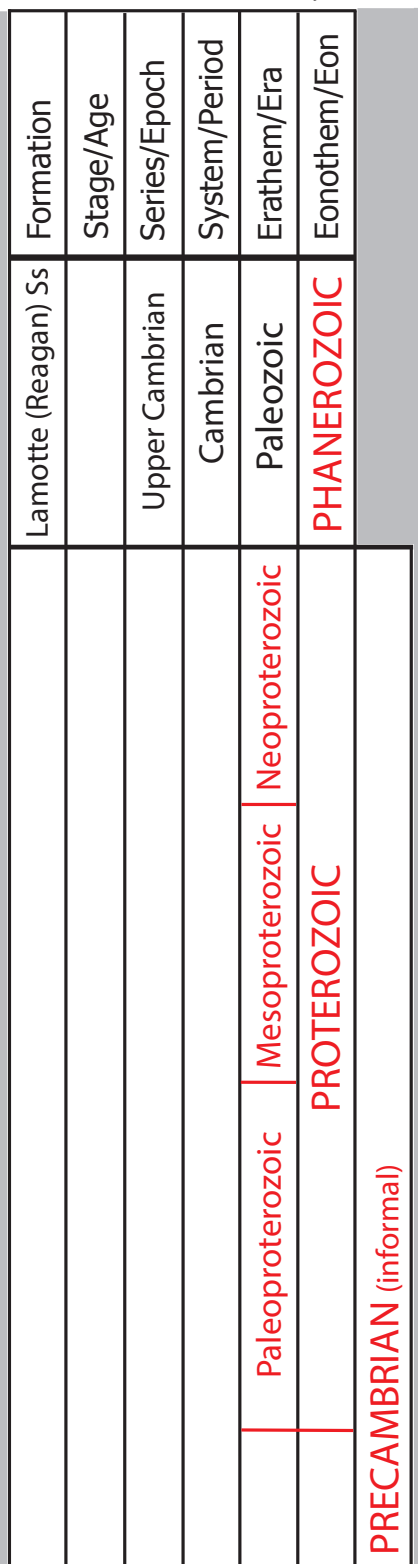

这 ICS Nomenclature
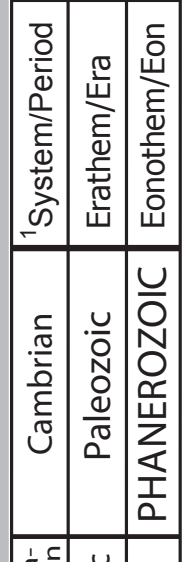

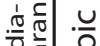

谉

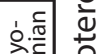

额

(1).:

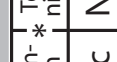

密. 등.

$\because *-$

空.

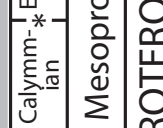

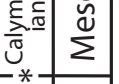

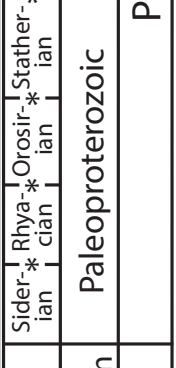

iา

Z

$\sum * \frac{\pi}{c}$

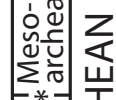

$\therefore \rightarrow$

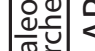

\%ำ

$-*$

ì $\frac{\tau}{\mathrm{c}}$

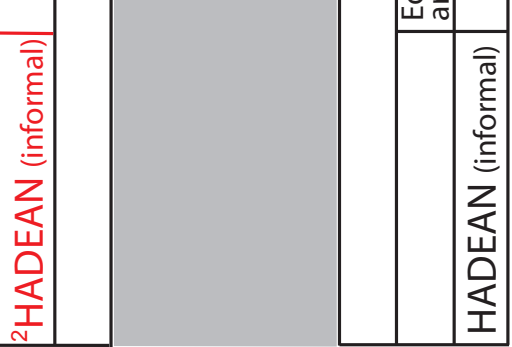

Figure 2-Precambrian nomenclature changes to Zeller (1968) formally adopted by the KGS. Left column: Zeller (1968). Center column: This paper, with changes highlighted in red. Right column: ICS nomenclature-boundaries with asterisks (*) have not been ratified by the ICS/IUGS (International Commission on Stratigraphy, 2013). ${ }^{1}$ Only the Ediacaran is a system/period; the underlying units are only periods because their GSSPs have not been established. ${ }^{2}$ Archean and Hadean rocks are not known to occur in Kansas. 


\section{References}

Anderson, R. R., 1990, Review of the Precambrian geological history of the central United States and the Midcontinent Rift System, in, The Amoco M. G. Eischeid \#1 deep petroleum test, Carroll County, Iowa, R. R. Anderson, ed.: Iowa Geological Survey, Special Report Series No. 2, 185 p.

Berendsen, P., 1994, Review of Precambrian rift stratigraphy, in, Revision of Stratigraphic Nomenclature in Kansas, D. L. Baars (compiler): Kansas Geological Survey, Bulletin 230, p. 1-4.

Berendsen, P., 1997, Tectonic evolution of the Midcontinent Rift System in Kansas, in, Middle Proterozoic to Cambrian Rifting, Central North America, R. W. Ojakangas, A. B. Dickas, and J. C. Green, eds.: Geological Society of America, Special Paper 312, p. 235-241.

Berendsen, P., and Barczuk, A., 1993, Petrography and correlation of Precambrian clastic sedimentary rocks associated with the midcontinent rift system: U.S. Geological Survey, Bulletin 1989-E, 20 p.

Berendsen, P., Borcherding, R. M., Doveton, J., Gerhard, L., Newell, K. D., Steeples, D., and Watney, W. L., 1988, Texaco Poersch \#1, Washington County, Kansas-Preliminary geologic report of the prePhanerozoic rocks: Kansas Geological Survey, Open-file Report 8822, $116 \mathrm{p}$.

Bickford, M. E., Harrower, K. L., Nusbaum, R. L., Thomas, J. J., and Nelson, G. E., 1979, Preliminary geologic map of the Precambrian basement rocks of Kansas: Kansas Geological Survey, Map, no. M-9, 1 sheet, scale 1:500,000.

Bleeker, W., 2004, Toward a "natural" Precambrian time scale; in, A Geologic Time Scale 2004, F. M. Gradstein, J. G. Ogg, and A. G. Smith, eds.: Cambridge University Press, p. 141-146.

Brasier, M., Cowie, J., and Taylor, M., 1994, Decision on the PrecambrianCambrian boundary stratotype: Episodes, v. 17, nos. 1 and 2, p. 3-8.

Cloud, P., 1972, A working model of the primitive Earth: American Journal of Science, v. 272, no. 6, p. 537-548.

Cullers, R. L., and Berendsen, P., 1993, Composition of rift-related igneous and sedimentary rocks of the Keweenawan Supergroup in the Poersch no. 1, OZ-1, Finn, and Friederich wells, northeastern Kansas: Kansas Geological Survey, Current Research on Kansas Geology, Bulletin 235, p. 55-72.

Dickas, A. B., 1986, Comparative Precambrian stratigraphy and structure along the Mid-continent Rift: American Association of Petroleum Geologists Bulletin, v. 70, no. 3, p. 225-238.

Gradstein, F. M., Ogg, J. G., Schmitz, M. D., and Ogg, G. M., eds., 2012, The Geologic Time Scale 2012: Elsevier, 1,144 p.

Gradstein, F. M., Ogg, J. G., Smith, A. G., Bleeker, W., and Lourens, L. J., 2004, A new geologic time scale, with special reference to Precambrian and Neogene: Episodes, v. 27, no. 2, p. 83-100.
International Commission on Stratigraphy, 2013, International Chronostratigraphic chart (January 2013): http://www.stratigraphy. org/index.php/ics-chart-timescale.

Knoll, A. H., Walter, M. R., Narbonne, G. M., and Christie-Blick, N., 2006, The Ediacaran Period: A new addition to the geologic time scale: Lethaia, v. 38, p. 13-30.

Koester, E. A., 1935, Geology of Central Kansas Uplift: Bulletin of the American Association of Petroleum Geologists, v. 19, no. 10, p. $1,405-1,426$.

Muehlberger, W. R., Denison, R. E., and Lidiak, E. G., 1964, Buried basement rocks of the United States of America and Canada: University of Texas, Austin, Final Report, Contract AF49(638)-1115/ ARPA Order No. 180-62, v. 1, 213 p.

North American Commission on Stratigraphic Nomenclature, 2005, North American stratigraphic code: American Association of Petroleum Geologists Bulletin, v. 89 , p. 1,547-1,591.

Plumb, K. A., 1991, New Precambrian time scale: Episodes, v. 14, no. 2, p. $139-140$.

Robb, L. J., Knoll, A. H., Plumb, K. A., Shields, G. A., Strauss, H., and Veizer, J., 2004, The Precambrian: the Archean and Proterozoic Eons; in, A Geologic Time Scale 2004, F. M. Gradstein, J. G. Ogg, and A. G. Smith, eds.: Cambridge University Press, p. 129-140.

Scott, R. W., 1966, New Precambrian(?) formation in Kansas: American Association of Petroleum Geologists Bulletin, v. 50, no. 2, p. 380-384.

Van Kranendonk, M. J., 2012, A chronostratigraphic division of the Precambrian; in, The Geologic Time Scale 2012, F. M. Gradstein, J. G. Ogg, M. D. Schmitz, and G. M. Ogg, eds.: Elsevier, p. 299-392.

Van Kranendonk, M. J., Gehling, J., and Shields, G., 2008, Precambrian; in, The Concise Geologic Time Scale, J. G. Ogg, G. Ogg, and F. M. Gradstein, eds.: Cambridge University Press, p. 23-36.

Van Schmus, W. R., and Bickford, M. E. (eds.), 1993, Transcontinental Proterozoic provinces (Chapter 4); in, Precambrian: Conterminous U.S., J. C. Reed, Jr., M. E. Bickford, R. S. Houston, P. K. Link, D. W. Rankin, P. K. Sims, and W. R. Van Schmus, (eds.): Geological Society of America, The Geology of North America, v. C-2, p. 171-334.

Van Schmus, W. R., and Hinze, W. J., 1985, The Midcontinent Rift System: Annual Review of Earth and Planetary Sciences, v. 13, p. 345-383.

Zeller, D. E., ed., 1968, The stratigraphic succession in Kansas: Kansas Geological Survey, Bulletin 189, 81 p., 1 plate.

\section{KGS Stratigraphic Nomenclature Committee}

This paper was completed by current members of the Kansas Geological Survey's Stratigraphic Nomenclature Committee, which was re-established in July 2005, to address stratigraphic issues and establish formally accepted stratigraphic nomenclature for Kansas. The Stratigraphic Nomenclature Committee is the official arbiter of stratigraphic nomenclature and issues in Kansas, subject to review by the State Geologist. More information about the Committee and Kansas stratigraphic nomenclature is available at http:// www.kgs.ku.edu/General/Strat/index.html.

The Kansas Geological Survey recognizes Zeller (1968) as the current accepted guide and chart for Kansas. Nomenclature changes will follow the North American Stratigraphic Code (2005), and changes will conform to international stratigraphic nomenclature standards as they apply to Kansas.

\section{Acknowledgments}

The authors thank Drs. Raymond Anderson and Robert Cullers for constructive technical reviews that improved the clarity of the manuscript. We also thank Dr. Randall Van Schmus for his informal review. Julie Tollefson is thanked for editorial and publication assistance, and Cathy Evans for suggestions that improved the writing quality. 